\title{
KNOWLEDGE, ATTITUDE AND PRACTICE TOWARDS SEXUAL AND REPRODUCTIVE HEALTH INCLUDING COMPREHENSIVE SEXUALITY EDUCATION AMONG FIRST YEAR STUDENTS OF UNIVERSITY MALAYSIA SABAH (UMS), MALAYSIA
}

\author{
San San Win ${ }^{1}$, Helen Benedict Lasimbang ${ }^{1}$, Mie Mie Cho Win ${ }^{1}$, M Tanveer Hossain Parash ${ }^{2}$, Sai Nay \\ Lynn Aung ${ }^{3}$, Yeap Boon Tat ${ }^{4}$ and Than Myint ${ }^{5}$. \\ ${ }^{1}$ Reproductive Health Department, Faculty of Medicine and Health Sciences, University Malaysia Sabah, 88400 Kota \\ Kinabalu, Sabah, Malaysia \\ ${ }^{2}$ Department of Biomedical Science and Therapeutics, University Malaysia Sabah, \\ ${ }^{3}$ Independent Consultant, Master of Arts (Population and Reproductive Health Research) \\ ${ }^{4}$ Medicine Based Department, Faculty of Medicine and Health Sciences, University Malaysia Sabah \\ ${ }^{5}$ Retired Director General, Department of Medical Sciences, Myanmar.
}

\section{Corresponding author: San San Win}

Email: drsanwin@gmail.com

\begin{abstract}
This study aims to assess knowledge, attitude and behavior in sexual and reproductive health (SRH) including comprehensive sexuality education (CSE) among 439 first year students; 213 sciences and 226 arts students from 5 Faculties of University Malaysia Sabah (2016-2017). Exposure of Malaysian students to sexual education is limited to science subjects which are only being taught at upper elementary and secondary high school levels. Arts students are less exposed to sexual education across Malaysia as it is delivered in Basic Science subject only. It was a university-based, cross-sectional, descriptive study. Pretested self-administered questionnaire was anonymously completed by all participants and was conducted from November 2016 to January 2017. Students' demographic characteristics from Science and Arts streams were same except females, Sabah ethnics and Malays were more in Arts. Awareness of HIVIAIDS, Condom, Wet dream, COC pills and abortion services were more in Science students and statistically significant. $34.3 \%$ and $81.2 \%$ of Science students agreed that CSE should be introduced in primary and secondary school but not statistically significant. 22 out of 439 students were sexually active. Science students had more knowledge about SRH and favourable attitude towards sexuality education but less favourable behaviour of watching and reading pornographic materials. It was concluded that there were gaps in knowledge, attitude and behaviour of SRH and need to remedy these by giving appropriate CSE classes to first-year university students in an elective module according to their culture and religious beliefs in accord with International Technical Guidance on Sexuality Education (ITGSE).
\end{abstract}

Keywords: Knowledge, Attitude, Behaviour, Sexual and Reproductive Health (SRH), Comprehensive sexuality Education (CSE), first year university students.

\section{INTRODUCTION}

Comprehensive Sexuality Education (CSE) includes age-appropriate, medically accurate information on a broad set of topics related to sexuality including human development, relationships, decision making, abstinence, and contraception and disease prevention. They provide students with opportunities for developing skills as well as learning. However, exposure of Malaysian students to sexual education is limited to science subjects which are only being taught at upper elementary and secondary school levels. ${ }^{(1)}$ UNESCO's International Technical Guidance on Sexuality Education (ITGSE) ${ }^{(2)}$ identifies that effective CSE programmes can reduce misinformation, increase correct knowledge, clarify and strengthen positive values and attitudes, increase skills to make informed decisions and act upon them, improve perceptions about peer groups and social norms and increase communication with parents or other trusted adults. A commentary paper suggests that programmes implemented according to UNESCO's standards increase awareness and change attitudes on gender equality and power structures ${ }^{(3)}$. Although there is plenty of evidence for changing sexual behaviors, there is no focus as yet on other outcomes, such as gender equality, critical thinking, empowerment, or confidence ${ }^{(4)}$. Haberland and Rogow mentioned that an approach to CSE which emphasizes gender, power and rights has a greater likelihood of reducing rates of sexually transmitted infections and unintended pregnancy. ${ }^{(5)}$

In Malaysia, a study on risk and protective factors affecting adolescents 'sexual and reproductive health' in Peninsular Malaysia performed by National Population and Family Planning Board stated that knowledge of Sexual and reproductive health is one of the protective factors and measures such as sex education and awareness 
programs are needed among youths. (6) According to a study conducted among secondary school students in Pulau Pinang, Malaysia in 2010, knowledge about sexual health and sexually transmitted illnesses (STI) was insufficient although many of the respondents participated in high risk sexual behaviors.(7 ) The authors recommended further analysis on the knowledge, attitude and behavior of Malaysian students towards CSE is warranted to curb the increasing rates of unplanned pregnancies, teenage marriages and STI. Another study conducted in Universiti Kebangsaan Malaysia (UKM) in 2012 among 380 university students after 13 hours of sex education program based on the sexuality education curriculum by UNESCO (2009) also strongly recommended that sex education should be implemented in Malaysian schools with meticulous planning by starting with students in form 3 and being taught in separate classes for boys and girls respectively while relating it to the perspective of Islam. Moreover, arts students are less exposed to sexual education than science students in classrooms across Malaysia as it is most delivered through the Basic Science subjects in secondary schools. (8)

As yet there is not enough research conducted to make a definitive statement on Knowledge, Attitude and Behavior regarding SRH of CSE on large scale between Science and Arts students in Malaysia Universities.

Our objective is to detect differences in knowledge, attitude and behavior of SRH regarding CSE among first year students from Faculties of Science and Faculties of Arts of UMS.

\section{METHODS}

A University-based, cross sectional, quantitative, descriptive and comparative study was conducted among First year students (2016-2017) from three science and two arts faculties of University Malaysia Sabah (UMS) during November 2016 to January 2017. UMS have 10 faculties with 6 sciences and 4 arts faculties. There were 4,482 students in 2015-2016 academic year with 1,632 in sciences and 2,850 in arts respectively. With 3\% error and $10 \%$ non-respondents, the sample size was 439 first year students from five faculties involved according to the prevalence of premarital sex among Malaysian students which was $2.6 \%$ in male and $0.062 \%$ in female population. (9)

\section{$N=\frac{Z^{2} 1-a l p h a / 2 \times p(1-p)}{d^{2}}$}

Inclusion criteria were First year students from chosen Science and Arts Faculties. Exclusion criteria were First year students from chosen faculties who were not willing to participate after they read the provided subject information and pre- tested questionnaire of the research. Faculty of Medicine and Health Sciences, one science and one arts faculty which were chosen to pretest the questionnaire and 2 faculties outside Kota
Kinabalu Campus of UMS were also excluded from the study. Written informed consent was taken after the subject information of the research in both Bahasa Melayu and English languages were distributed. After getting their informed consent, pretested questionnaires were completed by the participants anonymously.

\section{Questionnaire}

We used the questionnaire adapted from a study on risk and protective factors affecting adolescents' sexual and reproductive health in Peninsular Malaysia performed by National Population and Family Planning Board. ${ }^{(6)}$ The questionnaire includes 23 items regarding awareness and knowledge of $\mathrm{SRH}, 9$ items regarding attitude on sexual education and $\mathrm{SRH}$ and 7 items regarding previous practices pertaining to sexual and reproductive health. The ethical approval was taken from Ethical committee of University Malaysia Sabah, Malaysia. Deans of all chosen 5 faculties were requested for permission to conduct the study through their head of academic unit.

\section{Statistical analysis}

Data were analysed using Statistical Package for Social Sciences (SPSS) for Windows version 22.0. Comparisons among groups were made using appropriate inferential tests such as student $\mathrm{t}$ test, Fisher's exact test and Chi square test. Statistical significance level used was 0.05 .

\section{RESULTS}

A total of 439 First year students participated in the study and Arts students were more than Sciences students $(51.5 \%$ Vs $48.5 \%)$. Female students were more than male students $(62.0 \%$ Vs $38.0 \%)$ in Science and (73.5\% Vs $26.5 \%)$ in arts stream which was statistically significant and shown in Table(1). SRH awareness was more in Science students regarding HIV/AIDS, Condom, Wet dream, COC pills and abortion services which all were statistically significant and shown in Table (2). Overall review on $15 \mathrm{SRH}$ knowledge assessment questions, Science students had more correct answers than art students in 8 questions and was statistically significant and shown in Table ( $3 \mathrm{a}$ and $\mathrm{b}$ ). The distribution of level of agreement was shown in Table (4 a and b) as follows; Science students who indicated that sexual education should be introduced in primary school were 34.3 percent and 81.2 percent in secondary school respectively. They strongly agreed and agreed that sexual education to adolescents would increase social problems accounted for 32.4 percent. 62.0 percent of 
Science students who strongly agreed and agreed that all forms of pornography should be banned. Regarding Arts students, 27.9 percent of them strongly agreed and agreed that sexuality education should be introduced in primary school and 71.7 percent in secondary school. 33.2 percent of arts students who strongly agreed and agreed that sexual education to adolescents would increase social problems. 67.3 percent of them also strongly agreed and agreed that all forms of pornography should be banned. Abortion can be carried out for pregnancy resulted from premarital sex was strongly agreed by science students (10.3\%) and by arts students (4.4\%) and it was statistically significant $(p=0.033)$. Sciences students scored more on SRH knowledge than arts students $9.76 \pm 2.49$ Vs $8.75 \pm 2.78$ which was

Table 1: Socio-demographic characteristics of the respondents

\begin{tabular}{|c|c|c|c|}
\hline Characteristics & Sciences N (\%) & ArtsN(\%) & $P$ value \\
\hline Total first year students & $213(48.5 \%)$ & $226(51.5 \%)$ & \\
\hline Age $($ Mean \pm SD $)$ & $19.9 \pm 1.183$ & $20.12 \pm 1.177$ & $0.054^{\mathrm{a}}$ \\
\hline \multicolumn{4}{|l|}{ Sex } \\
\hline Male & $81(38.0 \%)$ & $60(26.5 \%)$ & $0.010^{* c}$ \\
\hline Female & $132(62.0 \%)$ & $166(73.5 \%)$ & \\
\hline \multicolumn{4}{|l|}{ Ethnicity } \\
\hline Malay & $66(31.0 \%)$ & $84(37.2 \%)$ & \\
\hline Sabah ethnics & $52(24.4 \%)$ & $63(27.9 \%)$ & \\
\hline Other Bumiputera & $31(14.6 \%)$ & 18 (7.9\%) & \\
\hline Chinese & $36(16.9 \%)$ & $23(10.2 \%)$ & $0.031^{* c}$ \\
\hline Others & $28(13.1 \%)$ & $38(16.8 \%)$ & \\
\hline \multicolumn{4}{|l|}{ Religion } \\
\hline Islam & $123(57.7 \%)$ & $151(66.8 \%)$ & \\
\hline Buddhist & 27 (12.7\%) & $15(6.6 \%)$ & $0127 c$ \\
\hline Christian & $52(24.4 \%)$ & $52(23.0 \%)$ & 0.127 \\
\hline Hindu & $7(3.3 \%)$ & $5(2.2 \%)$ & \\
\hline Others & $4(1.8 \%)$ & $3(1.3 \%)$ & \\
\hline \multicolumn{4}{|l|}{ Marital Status } \\
\hline Single & $211(99.1 \%)$ & $224(99.1 \%)$ & \\
\hline Married & $2(0.9 \%)$ & $2(0.9 \%)$ & $1.000^{\mathrm{b}}$ \\
\hline
\end{tabular}

*Significant at 0.05 level, ${ }^{a}=$ student $t$ test

$b=$ Fisher's exact test, ${ }^{c}=$ Chi square test statistically significant ( $P$ <0.001). Three statements were analysed to assess students' attitude score towards sexual education and it was $29.94 \pm 3.76$ Vs $29.79 \pm 3.92$ but not statistically significant. $(P=0.689)$. Students' previous experiences in sexual activities were presented in Table (5). About 41.5 percent of Science students and 27.4 percent of Art students reported that they watched pornographic materials and was statistically significant ( $p$ $<0.002$ ). Mean age at first sex was 17.5 (SD \pm 1.286) year for Science students and 17.6 (SD \pm 1.549) year for arts students which is not statistically significant. $(p=0.852)$. One science student admitted that first sex was at 15 -yearold. 
Malaysian Journal of Public Health Medicine 2020, Vol. 20 (1): 184-191

Table 2: Awareness on sexual and reproductive health (SRH)

\begin{tabular}{|c|c|c|c|c|c|c|}
\hline \multirow{2}{*}{$\begin{array}{l}\text { Awareness on } \\
\text { SRH }\end{array}$} & \multicolumn{2}{|c|}{ Sciences $(\mathrm{N}=213)$} & \multicolumn{2}{|c|}{ Arts $(\mathrm{N}=226)$} & \multirow{2}{*}{$\mathbf{P}$} & \multirow{2}{*}{ value } \\
\hline & Yes & No & Yes & No & & \\
\hline Menstruation & $202(94.8 \%)$ & $11(5.2 \%)$ & $207(91.6 \%)$ & $19(8.4 \%)$ & & 0.178 \\
\hline HIV/AIDS & $193(90.6 \%)$ & $38(9.4 \%)$ & $188(83.2 \%)$ & $38(16.8 \%)$ & & $0.022^{*}$ \\
\hline Condom & $187(87.8 \%)$ & $26(2.2 \%)$ & $178(78.8 \%)$ & $48(21.2 \%)$ & & $0.012^{*}$ \\
\hline Wet dream & $166(77.9 \%)$ & $47(22.1 \%)$ & $155(68.6 \%)$ & $71(31.4 \%)$ & & $0.027^{*}$ \\
\hline COC pills & $154(72.3 \%)$ & $59(27.2 \%)$ & $142(62.8 \%)$ & $84(37.2 \%)$ & & $0.034^{*}$ \\
\hline Abortion services & $118(55.4 \%)$ & $95(44.6 \%)$ & $82(36.3 \%)$ & $144(63.7 \%)$ & & $<0.001^{*}$ \\
\hline $\begin{array}{l}\text { Someone who had } \\
\text { an abortion }\end{array}$ & $63(30.1 \%)$ & $150(69.9 \%)$ & $53(24.2 \%)$ & $173(75.8 \%)$ & & 0.167 \\
\hline $\begin{array}{l}\text { Emergency } \\
\text { contraceptive pill }\end{array}$ & $54(25.4 \%)$ & $159(74.6 \%)$ & $61(27.0 \%)$ & $165(73.0 \%)$ & & 0.696 \\
\hline
\end{tabular}

*Significant at 0.05 level

Table 3a: Students' knowledge on SRH

\begin{tabular}{|c|c|c|c|c|c|}
\hline \multirow[b]{2}{*}{ Knowledge on SRH } & \multicolumn{2}{|c|}{ Sciences $N=213$} & \multicolumn{2}{|c|}{ Arts $\quad \mathrm{N}=226$} & \multirow[b]{2}{*}{$P$ value } \\
\hline & $\begin{array}{l}\text { Correctly } \\
\text { answered } \\
N(\%)\end{array}$ & $\begin{array}{l}\text { Incorrectly } \\
\text { answered } \\
\text { N (\%) }\end{array}$ & $\begin{array}{l}\text { Correctly } \\
\text { answered } \\
\mathrm{N}(\%)\end{array}$ & $\begin{array}{l}\text { Incorrectly } \\
\text { answered } \\
\mathrm{N}(\%)\end{array}$ & \\
\hline $\begin{array}{l}\text { Pregnancy can be prevented by } \\
\text { using Condom }\end{array}$ & $147(69.0 \%)$ & $66(31.0 \%)$ & $133(58.8 \%)$ & $93(41.2 \%)$ & $0.002^{*}$ \\
\hline $\begin{array}{l}\text { Pregnancy can be prevented by } \\
\text { using birth control pills }\end{array}$ & $148(69.5 \%)$ & $65(30.5 \%)$ & $132(58.4 \%)$ & $94(41.6 \%)$ & $0.011^{*}$ \\
\hline $\begin{array}{l}\text { Pregnancy can be prevented by } \\
\text { avoiding Intercourse }\end{array}$ & $152(71.4 \%)$ & $61(28.6 \%)$ & $147(65.0 \%)$ & $79(35.0 \%)$ & $0.011^{*}$ \\
\hline $\begin{array}{l}\text { A woman cannot get pregnant if } \\
\text { she had sex only once }\end{array}$ & $140(65.7 \%)$ & $73(34.3 \%)$ & $120(53.1 \%)$ & $106(46.9 \%)$ & $0.026^{*}$ \\
\hline $\begin{array}{l}\text { Exchanging sex partner to disclose } \\
\text { sexually transmitted disease } \\
\text { (STD) }\end{array}$ & 195 (91.5\%) & $18(8.5 \%)$ & $201(88.9 \%)$ & $25(11.1 \%)$ & 0.611 \\
\hline $\begin{array}{l}\text { People with sexually transmitted } \\
\text { diseases may look like a normal } \\
\text { healthy person }\end{array}$ & $125(58.7 \%)$ & $88(41.3 \%)$ & $85(37.6 \%)$ & $141(62.4 \%)$ & $<0.001^{*}$ \\
\hline $\begin{array}{l}\text { Abortion cannot be done for any } \\
\text { reason under applicable laws in } \\
\text { Malaysia }\end{array}$ & $40(18.8 \%)$ & $173(81.2 \%)$ & $37(16.4 \%)$ & $189(83.6 \%)$ & 0.627 \\
\hline $\begin{array}{l}\text { HIV and AIDS can be transmitted } \\
\text { through sexual contact }\end{array}$ & $198(93.0 \%)$ & $15(7.0 \%)$ & $209(92.5 \%)$ & $17(7.5 \%)$ & 0.371 \\
\hline
\end{tabular}


Table 3 b : Students' knowledge on SRH

\begin{tabular}{|c|c|c|c|c|c|}
\hline \multirow[b]{2}{*}{ Knowledge on SRH } & \multicolumn{2}{|c|}{ Sciences $N=213$} & \multicolumn{2}{|c|}{ Arts $\quad \mathrm{N}=\mathbf{2 2 6}$} & \multirow[b]{2}{*}{$P$ value } \\
\hline & $\begin{array}{l}\text { Correctly } \\
\text { answered } \\
\mathrm{N}(\%)\end{array}$ & $\begin{array}{l}\text { Incorrectly } \\
\text { answered } \\
\mathrm{N}(\%)\end{array}$ & $\begin{array}{l}\text { Correctly } \\
\text { answered } \\
\mathrm{N}(\%)\end{array}$ & $\begin{array}{l}\text { Incorrectly } \\
\text { answered } \\
\mathrm{N}(\%)\end{array}$ & \\
\hline $\begin{array}{l}\text { Having sexual intercourse with a } \\
\text { woman who is having her period } \\
\text { would not lead to pregnancy }\end{array}$ & $100(46.9 \%)$ & $113(53.1 \%)$ & 78 (34.5\%) & $148(65.5 \%)$ & $0.030^{*}$ \\
\hline $\begin{array}{l}\text { A women can get pregnant if she } \\
\text { had sexual contact }\end{array}$ & $196(92.0 \%)$ & $17(8.0 \%)$ & $201(88.9 \%)$ & $25(11.1 \%)$ & 0.523 \\
\hline $\begin{array}{l}\text { Sex between men and women who } \\
\text { have never been to menstruation } \\
\text { cannot lead to pregnancy }\end{array}$ & $28(13.1 \%)$ & $185(86.9 \%)$ & $42(18.6 \%)$ & $184(81.4 \%)$ & $0.015^{*}$ \\
\hline Underage pregnancy remains risky & $145(68.1 \%)$ & $68(31.9 \%)$ & $141(62.4 \%)$ & $85(37.6 \%)$ & 0.313 \\
\hline $\begin{array}{l}\text { Having sexual intercourse with a } \\
\text { girl aged below } 16 \text { years is a rape } \\
\text { crime in Malaysia despite } \\
\text { consensual sex }\end{array}$ & 167 (78.4\%) & $46(21.6 \%)$ & $179(79.2 \%)$ & $47(20.8 \%)$ & 0.978 \\
\hline $\begin{array}{l}\text { A women can get pregnancy if } \\
\text { kissing a man }\end{array}$ & $202(94.8 \%)$ & $11(5.2 \%)$ & $204(90.3 \%)$ & $22(9.7 \%)$ & 0.193 \\
\hline $\begin{array}{l}\text { A woman cannot get pregnant if } \\
\text { she had sexual intercourse two } \\
\text { weeks prior to her next period }\end{array}$ & $95(44.6 \%)$ & $118(55.4 \%)$ & $68(30.1 \%)$ & $158(69.9 \%)$ & $<0.001^{*}$ \\
\hline
\end{tabular}

Table 4 a: Students' attitude on sexual education and SRH

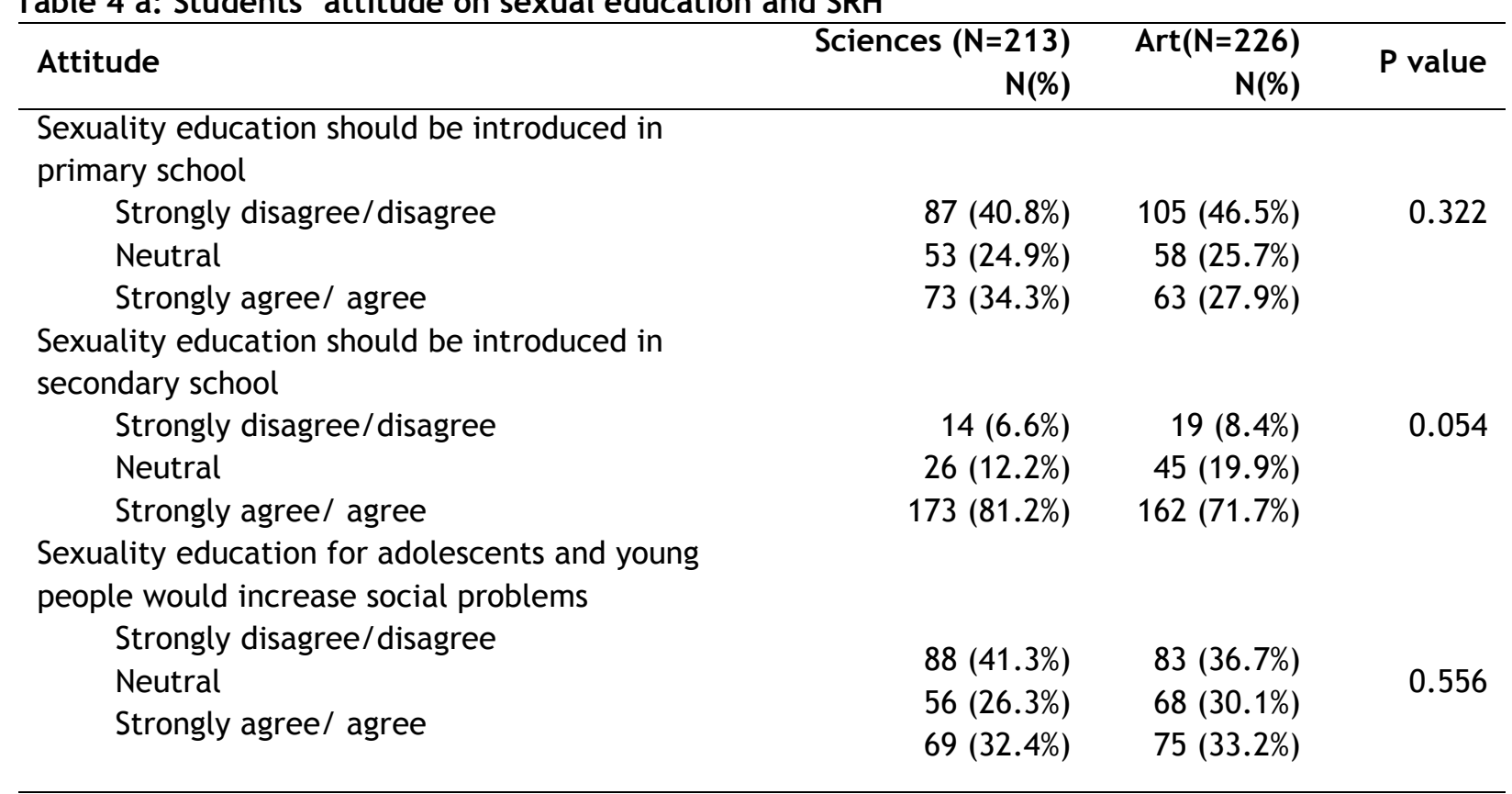


Table 4 b: Students' attitude on sexual education and SRH

\begin{tabular}{|c|c|c|c|}
\hline Attitude & $\begin{array}{r}\text { Sciences }(\mathrm{N}=\mathbf{2 1 3}) \\
\mathrm{N}(\%)\end{array}$ & $\begin{array}{r}\operatorname{Art}(\mathrm{N}=226) \\
\mathrm{N}(\%)\end{array}$ & $P$ value \\
\hline \multirow{2}{*}{\multicolumn{4}{|c|}{$\begin{array}{l}\text { Sex among unmarried young people is a serious } \\
\text { social problem }\end{array}$}} \\
\hline & $14(6.6 \%)$ & 10 (4.4\%) & \multirow{4}{*}{0.612} \\
\hline Strongly disagree/disagree & $16(7.5 \%)$ & $17(7.5 \%)$ & \\
\hline Neutral & $183(85.9 \%)$ & $199(88.1 \%)$ & \\
\hline \multirow{2}{*}{\multicolumn{4}{|c|}{$\begin{array}{l}\text { A woman will lose self-esteem and dignity if she } \\
\text { has sex before }\end{array}$}} \\
\hline & & & \\
\hline Strongly disagree/disagree & $17(8.0 \%)$ & $16(7.1 \%)$ & \multirow{3}{*}{0.325} \\
\hline Neutral & 30 (14.1\%) & 22 (9.7\%) & \\
\hline Strongly agree/ agree & $166(77.9 \%)$ & $188(83.2 \%)$ & \\
\hline \multirow{2}{*}{\multicolumn{4}{|c|}{$\begin{array}{l}\text { A man will lose self-esteem and dignity if he has } \\
\text { sex before marriage }\end{array}$}} \\
\hline & 37 (17.4\%) & $32(14.2 \%)$ & \multirow{3}{*}{0.496} \\
\hline $\begin{array}{l}\text { Strongly disagree/disagree } \\
\text { Neutral }\end{array}$ & $58(27.2 \%)$ & $57(25.2 \%)$ & \\
\hline Strongly agree/ agree & $118(55.4 \%)$ & $137(60.6 \%)$ & \\
\hline \multicolumn{4}{|l|}{$\begin{array}{l}\text { Hugging kissing is acceptable as long as it does } \\
\text { not lead to sexual intercourse }\end{array}$} \\
\hline Strongly disagree/disagree & $139(65.3 \%)$ & $153(67.7 \%)$ & \multirow{3}{*}{0.657} \\
\hline Neutral & $33(15.5 \%)$ & $37(16.4 \%)$ & \\
\hline Strongly agree/ agree & $41(19.2 \%)$ & $36(15.9 \%)$ & \\
\hline \multicolumn{4}{|l|}{$\begin{array}{l}\text { Abortion can be carried out on pregnancy } \\
\text { resulted from premarital sex }\end{array}$} \\
\hline Strongly disagree/disagree & $169(79.3 \%)$ & $198(87.6 \%)$ & \multirow[t]{3}{*}{$0.033^{*}$} \\
\hline Neutral & $22(10.3 \%)$ & $18(8.0 \%)$ & \\
\hline Strongly agree/ agree & $22(10.3 \%)$ & $10(4.4 \%)$ & \\
\hline \multirow{3}{*}{$\begin{array}{l}\text { All forms of pornography should be banned } \\
\text { Strongly disagree/disagree } \\
\text { Neutral } \\
\text { Strongly agree/ agree }\end{array}$} & 42 (19.7\%) & 36 (15.9\%) & \multirow{3}{*}{0.473} \\
\hline & 39 (18.3\%) & $38(16.8 \%)$ & \\
\hline & $132(62.0 \%)$ & $152(67.3 \%)$ & \\
\hline
\end{tabular}

*Significant at 0.05 level

Table 5: Practice of previous experienced sexual activities

\begin{tabular}{lrrr}
\hline Practice of previous experienced sexual activities & $\begin{array}{r}\text { Sciences }(\mathbf{N}=213) \\
\mathbf{N}(\%)\end{array}$ & $\begin{array}{r}\text { Art (N=226) } \\
\mathbf{N}(\%)\end{array}$ & P value \\
\hline I read pornographic materials & $63(29.6 \%)$ & $53(23.5 \%)$ & 0.146 \\
I watch pornographic materials & $89(41.5 \%)$ & $62(27.4 \%)$ & $0.002^{*}$ \\
I have had sexual intercourse before & $11(5.2 \%)$ & $11(4.9 \%)$ & 0.887 \\
I have had sexual intercourse with prostitute before & $3(1.4 \%)$ & $0(0.0 \%)$ & $0.113^{\mathrm{a}}$ \\
I have had sex for rewards before & $2(0.9 \%)$ & $2(0.9 \%)$ & $1.000^{\mathrm{a}}$ \\
I have been pregnant before & $1(0.5 \%)$ & $1(0.5 \%)$ & $1.000^{\mathrm{a}}$ \\
I have caused someone pregnant before & $0(0.0 \%)$ & $0(0.0 \%)$ & $\mathrm{NA}^{\circ}$
\end{tabular}




\section{DISCUSSION}

Out of 10 faculties in UMS, we managed to recruit students from 5 faculties and it represented UMS students from both sciences and arts Streams. Arts students were more than Science students, female students were more than male students in this study as the enrolment of students to UMS was more female than male according to the 2015 statistics. This was in accord with other higher education centres as $60 \%$ of UKM students were female. ${ }^{(8)}$

The socio demographic characteristics of Science and Arts students were more or less the same; age, states of origin in Malaysia, ethnicity, religion, marital status. However, female gender, Malay race and Sabah ethnics were more in arts stream which were statistically significant. Malays were more than other races, Islam was more than other religions in this study was similar to other studies conducted in Malaysia. ${ }^{(9)}$

When awareness about SRH was analysed, Sciences students were much more aware of SRH than arts students. The arts students were more aware of emergency contraceptive pills and this knowledge was important to prevent unwanted pregnancies and its consequences like induced abortion and baby dumping. ${ }^{(10)}$ The rationale that Science students were more aware of SRH compared to arts students because they learned the compulsory science education under Science and Biology subjects from Form 1 to Form 5 while Arts students did not have a chance to learn this module in arts stream. (1) However, it was good to discover that some SRH topics were well known by arts students regarding sex between men and women who have never been to menstruation can lead to pregnancy and the meaning of rape as these knowledge might be acquired from out of school resources.

Regarding attitudes towards sexuality education, more science students agreed than arts students that it should be introduced in primary school by $34.3 \%$ and in secondary school by $81.2 \%$. This was in accord with one study regarding sexual education in Malaysia, whereby $74.3 \%$ agrees to introduce it to upper secondary school students, followed by $48.7 \%$ agrees to expose this module to lower secondary school students and finally $18.4 \%$ of participants agree to start sexual education as early as in primary school. (11)

Regarding behavior, science students read and watch more pornographic materials than arts students and it was strongly believed that this behaviour will influence their sexual activities. ${ }^{(8)}$ Very few science students had sexual intercourse with prostitutes but none in arts students. 2 students each in Sciences and Arts faculties admitted that they had sex for rewards. Students who had sexual experience before were probed further on their age at first sex. The age of first sex was 15-year in one Science student. This was also in accord with other study where $75 \%$ of school students aged between 15 to 20 years had their sexual debut at $15-19$ years. ${ }^{(7)}$

This study showed that the science and arts students' knowledge, attitude and practice of SRH in CSE were different.

\section{STRENGTH AND LIMITATION}

The strength of the study was two researchers supervised data collection, entry and cleaning process in 5 chosen faculties in UMS. There were limitations in this study as some important information which was related to student's selfreported history of sexual and reproductive health could lead to recall bias. It was performed in one university and the results could be reflected to the study population.

\section{CONCLUSION}

There were gaps in knowledge, attitude and behaviour of Sexual and Reproductive Health (SRH) including CSE among Sciences and Arts students in UMS. Science students more aware and knowledgeable about SRH and had positive attitude towards sexuality education but had a negative behaviour than arts students. Because of these differences in knowledge, attitude and behaviour of SRH in CSE among Arts and Sciences students of UMS, we need to remedy these differences by giving appropriate comprehensive sexuality education (CSE) to first year students as an elective module according to their culture and religious beliefs in accord with ITGSE 2018.

\section{ACKNOWLEDGEMENT}

We would like to thank to Deans and students from all five faculties for their agreement and involvement in this study. Our sincere thanks to Dean of Faculty of Medicine and Sciences and UMS Ethical clearance committee. Special thanks to Professor Dr Khaing Lay Mon from University of Public Health in Myanmar for final data analysis. Lastly to our families for their support during this study.

\section{CONFLICT OF INTEREST}

None and it was a self-funded study.

\section{REFERENCES}

1. Low WY. Impact of sexual health course on Malaysian University students. Med J Malaysia. 2004; 59(4):443-9.

2. UNESCO. International Technical Guidance on Sexuality Education, Volumes 1 and 2. Paris.2009 
3. Germain A. Commentary: Promoting healthy adolescent development through comprehensive sexuality education. Glob Public Health. 2015; 10(2):222-224. doi:10.1080/17441692.2014.986176

4. Boonstra, H. D. Advancing sexuality education in developing countries: evidence and implications. Guttmacher Policy Review.2011; 14(3),17-23. http://sparky.guttmacher.org/pubs/gpr/14 /3/gpr140317.html

5. Haberland, N., \& Rogow, D. Sexuality education: Emerging trends in evidence and practice. Journal of Adolescent Health. 2015; 56(1),S15-S21.

http://dx.doi.org/10.1016/j.jadohealth.201 4.08.013

6. National Population and Family Planning Board. A study on risk and protective factors affecting adolescents' sexual and reproductive health in Peninsular Malaysia. 2013

7. Anwar M, Sulaiman SA, Ahmadi K, Khan TM. Awareness of school students on sexually transmitted infections (STIs) and their sexual behavior: a cross-sectional study conducted in Pulau Pinang, Malaysia. BMC Public Health. 2010; 10:47. doi:10.1186/1471-2458-10-47

8. Talib J, Mamat M, Ibrahim M, Mohamad Z. Analysis on Sex Education in Schools Across Malaysia. Procedia - Soc Behav Sci [Internet]. 2012; 59(2005):340-8. Available from: http://dx.doi.org/10.1016/j.sbspro.2012.09 .284

9. Abdul Manaf MR, Tahir MM, Sidi H, Midin M, Nik Jaafar NR, Das $S$ et al. Pre-marital sex and its predicting factors among Malaysian youths. ComprehensivePsychiatry. 2014 Jan; 55(SUPPL. https://doi.org/10.1016/j.comppsych.2013. 03.008

10. Noordin N, Zakaria Z, Sawal MZHM, Hussin ZH, Ngah K, Nordin J. The Voice of Youngsters on Baby Dumping Issues in Malaysia. Int J Trade, Econ Financ. 2012;3(1):66-72.

11. Mutalip SSM, Mohamed R. Sexual education in Malaysia: Accepted or rejected? Iran J Public Health. 2012; 41(7):34-9. 